\title{
Teaching respect: a philosophical analysis
}

\author{
L. van Rooyen \& J. le Roux \\ Department of Educational Studies \\ University of Pretoria \\ PRETORIA \\ E-mail: Ivrooyen@hakuna.up.ac.za
}

\begin{abstract}
Teaching respect: a philosophical analysis

According to a Zulu proverb a human being can only become truly human because of others. Each person can only become more human, more himself - regardless of his sex - through the co-involvement of others. It is the love for one's neighbour and the respect one has for him/her as a person which makes one consider the other party's feelings, viewpoints and circumstances. In order to arrive at a situation of peaceful coexistence it is important to realize that human attitudes and a mature life style evolve through a process of learning and interaction with others. It is a timeconsuming and costly process which starts at infancy and continues throughout someone's life. Instruction concerning interpersonal relations and the teaching of respect cannot be confined to individual lessons or working sessions at home or in school. Discussions and conversations conceming interpersonal relations need to form an integral and natural part of a child's life within the home environment and throughout the pupil's school career. It is senseless if educators talk about the importance of teaching respect only to reveal disrespectful behaviour themselves, or to talk about the importance of self-esteem in the paying of respect whilst causing children to feel negative about themselves. To be able to express respect to other human beings, one needs to be respected. $A$ child needs to experience how it feels when homage is paid. The following rule of life applies in this regard: one can never give if one has never received respect.
\end{abstract}

\section{Introduction}

Enshrined in the Constitution of the Republic of South Africa (compare Beckmann et al., 1999:101) is the Bill of Rights which establishes a range of human rights and freedoms that are guaranteed. The Bill of 
Teaching respect: a philosophical analysis

Rights recognises that "everyone has a right to life" (s.11) and "everyone has inherent dignity and the right to have their dignity respected and protected" (s.10)

In the past the teaching of respect within the South African context, as elsewhere in the westernised world, focused almost exclusively on merely teaching boys how to respect girls and women as being the subordinate gender in society. The Constitution of the new South Africa dictates no discrimination between the sexes, with equal adjudication for women. The Bill of Human Rights stipulates that everyone is equal and has the right to equal protection and benefit of the law. Everyone has dignity as a human being - a dignity which must be respected and protected.

\section{Gender: in quest of a baseline for respect}

A Zulu proverb states that a human being can only become truly human because of others. In the same way this truth can be extended by stating that everyone can only become more human, more himself - regardless of his sex - through the co-involvement of others who join him on his journey from the past, through the present to the future: his/her real destination. Parents should no longer, as in the past when roles were clearly defined, teach only their sons to be independent, whilst teaching their daughters to be accommodating. Society and its demands have changed. Sex roles have changed. People have changed. Today, independence is expected of both sexes and altruism and respect are proclaimed by the leaders and peace-seekers of the world. These expectations are as highly valued in men as they have traditionally been in women - cf. Blankenstijn-Biersma (1986:11): "man en vrouw zijn gelijkwaardige 'partners' ... twee variaties van het mens-zijn".

It is a fact that males and females are genetically different. But whether there are congenital differences, acquired differences or culturally ascribed differences, whether each gender has different experiences and may even experience life differently, remains an open question. Both genders are human and experience a need for respect. The opposing positions of living and working find rich meaning and sense when men and women ultimately accept and acknowledge each other as equal partners committed to making the world a better place. Co-involvement means being committed to and responsible for each other, a partnership on all levels of man- and womanhood with each gender becoming more typically human, more fully man or woman because of the other.

Love for one's neighbour and the respect one has for him/her as a person which urges one to consider the other party's feelings, viewpoints 
and circumstances. It is because of respect that one feels concern and empathy for someone else. It is one's respect for another which urges one to contribute something to his/her well being. It is because of respect for someone else - a human being - that one cares about him/her, and values him/her.

\section{Respect for humanity}

The most significant issue of the day (crime, violence, race relations, economic and social justice, protection of the environment, to name only a few) often lead to diverse points of view and intellectual conflict. Not only in South Africa, but all over the world personalized crime with accompanying violence has reached alarming proportions in contemporary society. Arnold Toynbee, a world-famous historian, wrote that in world history, 19 out of 22 civilizations had collapsed when they had sunk to low moral levels (quoted in Greenberg, 1992:10). According to Toynbee, the average age of these civilizations at the time of their fall was 200 years. He indicates that nations complete a process from bondage to courage, to liberty, to abundance, to selfishness and complacency - only to start all over again in a state of bondage. In this regard it is wise to take note of the words of Plato: "In a climate of liberty ... regard and respect are no longer shown to anyone" (quoted in De Crescenzo, 1991:73).

As recently as the 1990's South Africa advanced to authentic democratic freedom and thereby set an example of peaceful negotiation to the world. Today in 2000 , this country is plagued by personalized and violent crime as being reported on a daily basis by means of the international news media. It seems as if peaceful negotiation, compromise, tolerance and mutual respect play a submissive role in human relations, especially in social and family life. Leaders who are deeply dismayed by the extent of crime and moral decay emphasize the importance of education for peace and the teaching of respect as an integral part of children's moral education. In this regard Heater $(1985: 266)$ emphasizes the fact that "... since wars begin in the minds of men, it is in the minds of men that the defences of peace must be constructed". Man is not only a homo sapiens, but also a homo pacix: a peace loving-being.

Political leaders in South Africa, who for many years relied on militaristic ways to resolve their differences, came to the parting of their ways in 1994. The turning point implied either the way of mutual respect and peace, or the road of brute force and violence. South Africans have chosen peaceful coexistence and non-violent processes to address problems. In the same way this truth needs to be extended to civilian and family level. South Africans need to open the window and face the 
Teaching respect: a philosophical analysis

ultimate truth: to respect one's fellow citizen and neighbour, his honour and reputation as well as his possessions - to care, value and regard others who share our world, life and sunshine are indispensable values. South Africans have to make a choice: on the one hand we have the safety of our children and families, the freedom and safety of the individual in the street and the security of society to consider, and on the other hand the alternative of slavery to crime and destruction. "Our fate will be determined by our hearts" (Hollins, 1966:313).

It is every educator's task and duty to guide children towards an understanding of right and wrong, to respect someone else, his viewpoints as well as his person and property. Education, whether informal at home or formalised at school, should be a manifestation of democratic group life. How is it that we prepare our children for a complex and changing world but often not the supporting values? What about faith and inner calm? What about peace of mind, happiness, the enjoyment of living, consideration and the ability to give and receive love? What about confidence, self-discipline and self-respect? What about interpersonal skills, how to care, to value, regard and respect? For too long we have disregarded these aspects as core elements of the domain of education (Ntuli, 1999:15). We tend to assume that people acquire these values naturally and develop these aspects in their own time and in their own way: that for instance regard and respect are mainly "caught" and not "taught".

\section{Respect: a philosophical analysis}

\subsection{Defining the concept respect}

A wide range of different, though interrelated connotations and subtle variations in meaning are attached to the concept respect. Many such variations are covered by related concepts such as "respect(s)", "respect for", "respectable", "respectability", "respecter", "respectful", etc. concepts with subtle nuances in meaning which are often used interchangeably

The Oxford Dictionary defines the concept respect as the "... message or attention conveying deferential esteem; to treat or regard with deference, esteem, or honour; treat with consideration" (McKenzie \& Augarde, 1984:250). The concept respect can also refer to "... pay heed to; relate to, be concerned with; avoid degrading or insulting or injuring or interfering with or interrupting, treat with consideration, spare" (Fowler \& Fowler, 1972:1060). It is interesting to note that the concept respect in Latin (respectus, respicere) means to look back to consider ("to pay 
L. van Rooyen \& J. le Roux

attention to, to heed, regard or consider") (Emery \& Brewster 1948:1536; Kidd, 1991:578).

The discussion of respect as a human quality is based on the following assumptions:

- The concept respect is a human quality necessary for the peaceful coexistence of a family, society and nation(s) (Wilmot, 2000:44; Moremi, 1999:39);

- the ability to respect relates to a person's morality;

- respect is not genetically inherited or prenatally acquired, it is therefore not naturally "present" in a human being and does not form part of his natural constitution;

- respect as a human quality has to be taught to a child by both verbal instruction and the setting of a good example (Moremi, 1999:44);

- respect is therefore mainly taught, but by watching other people either in true life or on television, in films, etc., glimpses of respect and its positive effect can also be learned - a process which may reinforce what is taught to the child;

- respect as a human quality to be learned

- has been known since creation

- is philosophically embedded in the Greek concept of justice (De Crescenzo, 1991:63);

- is part of the educational equipment of a child, embedded in the concept authority and flows forth from the child's understanding acceptance and internalization of authority in his life (Pretorius 1988:16).

\subsection{Philosophical analysis}

\subsubsection{Respect: an educational philosophy}

Education is an ontological interhuman phenomenon, noticeable in the universal living reality - thus an ontological-anthropological fact. Man, capable of being educated, is dependent on the educative support of a fellow human being in his or her lifelong process of becoming (Langeveld, 1949:14). Without this support of the other, neither the individual's humanization (Van Rensburg et al., 1994:366-367) nor his or her education towards responsible adulthood with faith in Christ and to the glory of his name, can be realized (Deuteronomy 6:7) 
The human quality of being able to pay respect should be part of every responsible person's makeup. The teaching of respect is one of the overall goals in teaching democracy and peaceful coexistence (Department of Education, 1997a:5) and should form part of the broad education of any child.

Where education is concerned, aims and outcomes are always relevant. The overall aim of educating towards moral, independent, responsible and purposeful adulthood, which is universally directed towards upliftment, refinement and what ought to be, is endorsed and stressed by the teaching of respect.

The specific outcomes that are particularly relevant in the teaching of respect refer to the individual's

- understanding and acceptance of him- or herself as unique and worthwhile (self-respect is a pre-requisite for the payment of respect);

- demonstration of the values and attitudes necessary for a healthy and balanced lifestyle;

- utilisation of skills and displaying of attitudes and values that can improve relationships in families, groups and the community;

- respecting of the rights of others to hold personal beliefs and values;

- demonstration of values and respect for human rights as reflected in the underlying idea of ubuntu;

- practising of acquired life- and decision-making skills.

The above aims and specific outcomes are embedded in the twelve Critical Outcomes as formulated in Curriculum 2005 (Department of Education, 1997b:14-16) which are directed towards promoting the child's personal, family and communal life.

\subsubsection{Respect: a Christian philosophy}

Christian philosophy is founded in a theocentric approach according to which a child is incorporated in the covenant. This view is in accordance with the Order of Baptism, the Articles of Faith and the Word of God (Van Rensburg et al., 1994:345).

According to this view, God is the origin of everything. He reigns and rules over everything. He created according to His perfect will in which the order of creation is embedded. He determines the destination and purpose of all things and all people. 
L. van Rooyen \& J. le Roux

As human life, according to the Christian view, falls within the framework of orderly creation, so does the peaceful co-existence of mankind which is embedded in the Great Commandment to "love thy neighbour"" (Leviticus 18:19; Matthew 22:39; Mark 12:31; Luke 10:27; Romans 13:9; James $2: 8$ ). Guiding a child by means of teaching him or her to pay the necessary respect in fact only means to obey the Great Commandment and to try to maintain the order as meant by God throughout generations, or to restore it (Van Rooyen \& Louw, 1994:19; Educamus, 1994:18). Kant (1785) in this regard stresses the fact that according to the Protestant ethic not only the act of paying respect is important, but the fact that one has progressed to a higher moral niveau (Norman, 1985:95)

A philosophy of life forms the basis of a person's way of thinking and determines the way he or she reaches out to life or approaches reality or others. This means that he or she cannot reason independently of his or her philosophy of life. In the same way the relevant issue here, namely the payment of respect, will be discussed within the framework of a particular philosophy, namely a Christian philosophy.

\subsection{Respect: a typological analysis}

The philosophical foundations of respect cover such a vast and comprehensive field of knowledge that the typological analysis remains a problematic endeavour. From the many different types of respect distinguishable, the following five types have been identified for discussion in this article: evaluative respect, directive respect, institutional respect, obstacle respect and respect-for-humans.

\section{Evaluative respect}

Humans are social beings who need to relate to others, to affiliate, either on a personal or individual level, or on a macro societal scale. As society is stratified by various institutions and arrangements which make up the social order, individuals are known ("stratified") on the basis of their reputations, qualities, etc. There are various kinds of records, accounts and grading systems inherent in social systems and social life. It is through these differential systems that honour, rewards, prestige, renown, status, etc. are distributed and obtained (Hudson, 1978:11) Respect in this regard belongs to that group of attitudes that pays social tribute and homage to persons who meet the set standard.

When respect is merited, it is known as evaluative respect. Evaluative respect applies to specific characteristics of a person, e.g. honesty, integrity, etc. Hudson (1978:19) mentions the fact that this form of respect contains a qualifier e.g. "highly" which implies that the person who is respected should meet the requirements of a set of standards. 
Concerning this, Hudson (1978:19) states the following: "Objects can rate higher or lower on such standards, and hence be worthy of respect to a greater or lesser degree ...". To respect someone or something is to consider the person or object worthy of respect - he or she has to be "approved by others" (Romans 14:18). In this instance the person is empowered with authority and acts on the authority of those characteristics which can be respected

It is important to emphasise the fact that evaluative respect presupposes an evaluative appraisal of a ranking of grading type: it means that respect is paid towards someone for a particular reason. This means we can "like" a person for no reason whatsoever, but we cannot respect a person for no reason at all. "Part of the feeling of esteem is to have a certain feeling toward some object in virtue of something taken to be a fact about that object" (Hudson 1978:12). In this regard Kant (1785) holds the view that the payment of respect "for duty's sake" contributes to the formation of moral goodness in a child (quoted by Norman, 1985:95).

The opinion or judgmental view of a person when to respect or not is based on facts (as described above), as well as feelings which, as they are "paid out" and "received", play a special role in our interpersonal relationships (Hudson, 1978:11).

The following examples are descriptive of evaluative respect:

- John who from childhood on has been very interested in the earth's crust, highly respects Prof. Smith as a geologist.

- Martin could see the headmaster's respect for Peter's honesty in this matter.

- Joan, the team leader, is even more respected by her team mates after the excellent speech she has delivered.

It stands to reason that a child does not need to know the different types of respect as explained above. What is important, however, is to teach a child the knowledge and skills needed to pay the different kinds of respect. In the case of evaluative respect, to enable a child to respect someone on the grounds of a valued characteristic, an achievement or the position the person holds in society, he will need

- an understanding of right and wrong, good and bad which implies a firm set of norms based on moral and religious beliefs that guide and influence the child's behaviour; 
- the ability to distinguish, evaluate and choose between right and wrong, good and bad, the steadfastness to keep to his decision but the openness to alter his decision if it seems necessary;

- a clear value orientation: knowledge of the stratification of values from high to low, e.g. to know and be able to identify a valued characteristic;

- to be able to recognize, acknowledge and value the basis of authority from which the other person operates (reasons for respecting him).

\section{Directive respect}

A directive is something which must have the informative quality of a manual, an instruction or a guide, and should contain a key, a clue or a lead regarding the action or response of the addressee. The Bible with its instructions, commands, advice, etc. for a righteous living is a good example (Proverbs 10:7). Hudson (1978:18) focuses the attention on the request, command, piece of advice, rule, obligation-claim and right-claim included in commonplace directives. Examples of the most common forms of directive respect are illustrated by the following examples:

- When the new Property Act came into operation in South Africa in 1994, the property right of black and coloured people has been respected for the first time.

- After his serious accident John has new respect for a red robot.

- Susan respects her father's wishes and never stays out late.

- The lecturer respected the students' demands and postponed the test.

From the above examples it is clear that directive respect may be required, or even demanded (compare examples above), but may be wise (first three examples above) or foolish (fourth example above) not to obey.

To enable the child to show or not to show directive respect, he will e.g need

- an understanding of right and wrong, good and bad which implies a firm set of norms based on moral and religious beliefs that can guide and influence the child's decisions and behaviour;

- the ability to distinguish, evaluate and choose between right and wrong, good and bad (safety and danger) and keep to this decision;

- to be able to understand the advantage of the correct choice or when the opposite choice serves no good purpose; 
- a clear understanding of the rights of other people to exist and live a meaningful life which implies that they are entitled to their own particular viewpoint regardless of whether or not the child or his parents agree with or approve their views and ways (providing they are not transgressing statute or moral laws or harming anyone);

- to be able to recognize, acknowledge and value the basis of authority from where it originates (the reasons for respecting or not respecting it);

- to have a clear understanding of the causes and effects thereof

\section{Institutional respect}

In the case of institutional respect there is an underlying system of rules which indicates offices, roles, courtroom procedures, judicial activity, institutional structure, legal traditions and customs. Respect is shown by conforming one's behaviour to those conventions which prescribe respectful behaviour. For example, institutional respect due to a judge, is due in virtue of the institutions and arrangements that define the office of law. The following examples may clarify this kind of respect:

- People show their respect for the judge by standing up when he or she enters the court room.

- Mary respects the new flag of our country and stands up when the national anthem is sung

- Gusta shows her respect for parliament by wearing a hat to the opening ceremony

- Peter shows his respect by standing still when the funeral procession passes.

It stands to reason that a child does not know the different systems of rules in a country and will need time to learn the what, how and when of the different structures and institutions of society. It is, therefore, important that a child should be exposed to relevant situations, be guided with love and understanding whilst adults are setting a worthy example. In this regard Dallas (1972:103) remarks:

We educate our children more by what we do than by what we say and even more by what we are than by what we do. To put it in another way, the principle means by which we can help the child to develop towards adult maturity is by providing the personal example of our own adult life.

By offering the child regular and relevant opportunities and by motivating him/her to seize the moment. The child will soon know when and how to pay the necessary respect to social and national institutions. The child 
will also soon be knowledgeable regarding the correct social etiquette to suit the occasion.

The child will also need to

- have an understanding of right and wrong, good and bad in general, as well as correct and incorrect behaviour in accordance with certain social norms and values related to different social situations or circumstances, so that the child's decisions and behaviour would be guided and influenced:

- be offered enough suitable opportunities to learn;

- be able to ignore or postpone his own needs and to understand that own needs cannot, in certain circumstances, be met immediately;

- acquire the ability to distinguish between and evaluate certain situations and to make suitable choices and decisions;

- to be able to understand the advantages of a correct choice or to realise when and why wrong choices serve no good purpose;

- have a clear understanding of the way in which some people act in socially unacceptable ways in accordance with their viewpoints;

- to be able to recognize, acknowledge and value the authority from which the appeal is made (the reason for showing respect or not);

- to have a clear understanding of cause and effect.

\section{Obstacle respect}

In obstacle respect a characteristic barrier exists that needs to be overcome, bypassed, or to receive some appropriate treatment if one is to complete a task successfully or attain a goal. This item (or barrier) serves as an obstacle or potential hazard (Hudson, 1978:30). It is important to note that the aim is explicitly recognizable.

The following examples illustrate obstacle respect

- The zoo keeper shows his respect for the lions by keeping a safe distance.

- The racing driver shows his respect for the sharp curve in the road by reducing his speed to a safe eighty kilometres per hour.

- Sharon is a good mountaineer and she respects the hazards of Table Mountain. 
For a child to be able to show obstacle respect, it is important to have

- a thorough understanding of the dangers and risks which reside in certain objects, natural phenomena, situations, etc.;

- the ability to distinguish, evaluate and choose between right and wrong, good and bad, safe and dangerous options;

- the ability to stick to a decision, not yield to temptation and not to be reckless when the opportunity arises;

- an understanding of the advantages of the correct choice or to realise when the incorrect choice serves no good purpose;

- the ability to be steadfast in decisions when other people behave irresponsibly and against circumstantial requirements or socially acceptable rules of safety;

- the ability to recognize, acknowledge and value the authority of an obstacle, barrier or danger (the reason for showing respect).

\section{Respect-for-humans}

The discussion of this particular kind of respect is mainly based on the following three assumptions:

- human beings are all of equal value;

- human beings are created in the image of God; and

- one must love one's neighbour ("love" equals "respect").

The concept respect-for-humans refers to the message that is sent from one person to another conveying deferential esteem. This kind of respect is shown when someone treats or regards another with deference, esteem, honour and consideration. Respect-for-humans belongs to that group of attitudes that pays social tribute and homage to other humans solely on the grounds that they are human beings. It is owed equally to all persons in virtue of their status as humans. Any person, good or bad, known or unknown, is entitled to such respect, solely in virtue of being a person.

Respect-for-humans requires that others be recognized and acted upon so as to attain the good of the other and to satisfy their interests, aims, objectives and purposes. To show respect-for-humans is the obligation and privilege of everyone (Eze, 1998:15). It implies a kind of respect that one should be eager to pay and is an indication of someone's democratic characteristics and level of refinement. According to a Christian perspective one should strive to precede the other in the payment of this kind of respect (Hebrews 13:16). This attitude is also customary in 
Western society (Brendtro \& Long, 1996:12). Every person should set a good example (1 Tim. 4:12) which can contribute to the payment of mutual respect and thereby making the world a better place for all humankind to live in.

In the understanding of the concept respect-for-humans in its relevancy to education, it is important to note that

- respect-for-humans is the reflexive application of the concept selfrespect (Hudson, 1978:13; Greenberg, 1992:11; De la Rey et al., 1997:110);

- every normal person has the potential or capability to fee/ respect;

- every person has unlimited resources of respect which can be distributed;

- respect-for-humans is not naturally present in every human being, but has to be taught to a child as part of the development of his moral character (Keatinge, 1917:212);

- when respect-for-humans is felt one can withhold expressing it;

- a distributor's supply of respect does not decrease through normal distributions;

- paying respect-for-humans has real value within the social framework because it contributes to the payment of reciprocal respect (Goduka \& Swadener, 1999:21) and an increased sense of well-being and positiveness within the involved participants.

Initially it is difficult for a child to pay respect to others, irrespective of who they are, solely by virtue of the fact that others are humans. A child needs to shift the focus from himself and his own well-being to include others and their well-being (De la Rey et al., 1997:122). It takes place through a process of learning and inner growth and the realization of the own responsibility towards others. It implies the development of the ability to not only feel a love for his neighbour but also to apply the rules of altruism and democracy in practice. To be able to show respect-forhumans, it is necessary for a child to

- realize that one stands under authority and is expected to pay the necessary respect-for-humans (role expectancy gives cause for role fulfilment);

- have a firm, positive sense of oneself, of one's own identity, selfesteem and self-efficacy "... so the individual needs not attempt to put others down in order to feel like somebody" (Greenberg, 1992:11); 
- be free from excessive anger because anger is usually inflicted upon others in one way or another;

- practise self-control (Brendtro \& Long, 1996:12);

- have a clear understanding of the rights of other people to co-exist and to have their own viewpoints, whether or not the child approves of their views and ways;

- be able to see a situation from another person's point of view - an ability on which respect is predicated. The child should also have the ability and preference for negotiating disagreements and resolving conflicts non-violently;

- acquire good communication skills in order to be able to convey views. The child should be aware of and understand verbal and nonverbal cues to prevent misunderstandings;

- be willing to recognize problems and be able and imaginative enough to generate alternatives (Greenberg, 1992:11);

- have the desire and ability to plan, work and make decisions cooperatively and reach consensus;

- be able to show empathy toward others who have less than he has, who are hurt and in pain, physically or emotionally, whether it is by casting a vote, writing a note, offering a soft shoulder, or covering your friend with your very own most precious security blanket (Greenberg, 1992:11);

- be motivated and capable to contribute to the well-being of others in a responsible way;

- be able to get along naturally and constructively with elders, the opposite sex, people of other races or status than his own;

- have a firm set of norms embedded in a moral and religious framework which can guide and influence the own thoughts and behaviour concerning ethical and controversial issues.

\section{Conclusion}

To arrive at a situation of peaceful co-existence it is important to realize that human attitudes and the life-style patterns of adults evolve through a process of learning and interaction with others. It is a timely and costly process which starts at infancy and continues throughout someone's life. Instruction concerning interpersonal relations and the teaching of respect cannot be confined to individual lessons or working sessions at home or in school. Discussions and conversations concerning interpersonal relations need to form an integral and natural part of a child's life in the 
home environment and throughout the pupil's school career. The role of the parent in collaboration with the teacher in this regard can never be over-emphasized. Due to the fact that parents are often ignorant in this regard, this issue shifts to the school and the responsibility solely rests on the shoulders of the teacher. "Society then looks to the school to produce future citizens who will be able to meet the challenge of a rapidly changing world ..." (Cunningham \& Radford, 1986:47).

It is in the classroom as an excellent workplace for democracy, that a child, through human relations, acquires a substantial portion of the knowledge and life-style patterns concerning interpersonal life skills. Human relations at school provide experiences which influence pupils' attitudes toward other people. It is, therefore, important that desirable norms, values and attitudes applicable to accepting others, paying respect and developing democratic characteristics be applied to everyday school life, in every lesson as well as in every classroom. Maria Montessori called for educators to progress from discipline as a verb (adults exercising control over students) to discipline as a noun (adults helping youth practise self-control) (Montessori, 1953:163). Teachers should, therefore, at all costs, avoid

... threatening abandonment or loss of love by parent, teacher, caregiver or God; withholding appropriate emotion or conversational response ('the silent treatment'); frightening, humiliating, shaming, embarrassing, ridiculing, or insulting the child in any way; making disparaging remarks about a child's race or interracial existence, religion or lack of it, family format (no father in the home, same-gender parents, unmarried parents) socio-economic level, etc.; labelling the child as 'bad' or 'naughty' and threatening physical punishment of any type (Greenberg, 1992:14)

It is senseless if educators talk about the importance of teaching respect only to reveal disrespectful behaviour themselves, or to talk about the importance of self-esteem in the paying of respect whilst causing children to feel negative about themselves.

To be able to pay respect toward other human beings, one needs to be respected. A child needs to experience how it feels when homage is paid. The following rule of life applies in this regard: one can never give if one has never received. How can one show compassion and consideration if one has never known the warmth of receiving, of being loved and cared for, if one is not understood, acknowledged and respected?

On a global scale, the net result of paying respect-for-humans is that a receiver of this kind of respect is more inclined than he would otherwise 
be to pay respect to others. In paying and receiving respect "... most social participants feel appreciated and better off" (Hudson, 1978:12). It heightens children's awareness of each other (De Crescenzo, 1991:74) and enhances empathy towards others (Greenberg, 1992:11). In this way children are prepared and motivated to co-operate and contribute to the well-being of others. It is in this context that the great Chinese philosopher, Lao Tzu, wrote that "... kindness in words creates confidence, kindness in thinking creates profoundness, and kindness in giving creates love".

\section{Bibliography}

ARNOT, M. ed 1988. Race and gender. Oxford: Pergamon Press

BECKMANN, J., BRAY, E., FOSTER, W.F., MAILE, S. \& SMITH, W.J. 1999. The legislative framework for human resource management \& development in the education \& training sector. Pretoria : University of Pretoria. Canada-South Africa Education Management Program.

BRENDTRO, L. \& LONG, N. 1996. Rethinking respect. Child and Youth Care, 14(5):12-13.

BLANKENSTIJN-BIERSMA, T. 1986. Waarom seksuele opvoeding? Nijkerk Callenbach

CUNNINGHAM, K.S. \& RADFORD, W.C. 1986. Training the administrator. A study with special reference to education. Victoria : ACER.

DALLAS, DM 1972. Exploring education: Sex education in school and society. USA : National Foundation of Research

DE CRESCENZO, L. 1991. The history of Greek philosophy. London : Pan Books.

DE LA REY, C., DUNCAN, N., SHEFER, T. \& VAN NIEKERK, A. 1997. Contemporary issues. Halfway House : International Thomson Publishing.

DEPARTMENT OF EDUCATION 1997a. Policy document Senior phase (Grades 79). Pretoria : Government Printers.

DEPARTMENT OF EDUCATION 1997b. Curriculum 2005. Pretoria : Government Printers.

EDUCAMUS. 1994. Building respect, responsibility and spiritual values. Educamus, 40(3): 17-23.

EMERY, H.G. \& BREWSTER, K.G., ed. 1948. New century dictionary of the English language. New York: Appleton Century.

EZE, E C 1998 African philosophy London: Blackwell

FOWLER, H.W \& FOWLER, S.G. 1972 Concise Oxford dictionary. London : Oxford University Press

GODUKA, MI. \& SWADENER, B.B. 1999. Affirming unity in diversity: healing with ubuntu. Kenwyn : Juta.

GREENBERG, P. 1992. Ideas that work with young children. Young Children: 35-37, Jul.

HEATER, D. 1985. Peace and war since 1945. London : Parrap Press.

HOLLINS, P.L. 1966 Essays on political education London : Longman.

HUDSON, SD. 1978. Self-respect and character Pittsburgh : University of Pittsburgh. (Ph D thesis.)

KEATINGE, MW. 1917. The great didactic Johan Amos Comenius New York MacMillan Col

KIDD, D A. 1991. Collins Gem Latin Dictınary Glasgow HarperCollıns Publıshers 
L. van Rooyen \& J. le Roux

LANGEVELD, M.J. 1949. Beknopte Theoretische Paedogiek. Groningen : Wolters

MCKENZIE, D C. \& AUGARDE, J.C. 1984. The Oxford dictionary. Fifth Impression. London : Oxford University Press.

MONTESSORI, M. 1953. Door het kind naar een nieuwe wereld. Tweede druk Heiloo : Kinheim Uitgeverij

MOREMI, S. 1999. The respect for cultural diversity program. Bulletin for Educational Technology. (1):39-45.

NORMAN, R. 1985. The moral philosophers. An introduction to ethics. Oxford : University Press.

NTULI, P.P. 1999. The missing link between culture and education: are we still chasing gods that are not our own? (In Makgoba, M.W., ed. African Renaissance The new struggle. Cape Town: Tafelberg p. 188.)

PRETORIUS, J.W.M. 1988. Opvoeding, samelewing, jeug. Pretoria : Van Schaik.

VAN RENSBURG, C.J.J., LANDMAN, W.A. \& BODENSTEIN, H.C.A. 1994. Basiese begrippe in die Opvoedkunde. Basic concepts in education. Sesde Uitgawe. Pretoria : Perskor Boekdrukkers.

VAN ROOYEN, L. \& LOUW, N. 1994. Sexuality education - A guide for educators. Pretoria : Van Schaik.

WILMOT, J. 2000. Values, democracy and education. A research report. Cape Town : University of Cape Town

\section{Key concepts:}

consideration.

deference

esteem

moral education

respect

\section{Kernbegrippe:}

aanleer van moraliteit

agting

eerbied

ontsag

respek 